\title{
Open Distance Learning Students' Perception Of The Use Of Social Media Networking Systems As An Educational Tool
}

\author{
Jan Wiid, DCom, University of South Africa, South Africa \\ Michael C. Cant, Ph.D., University of South Africa, South Africa \\ Corinne Nell, University of South Africa, South Africa
}

\begin{abstract}
Students in tertiary institutions have become more and more adapted to the use of technology, which is especially important for the businesses that hire graduates. Students are increasingly expected by employers to be proficient in the use of social media and therefore expect their institutions to make use of similar technology in the delivery of educational materials. The main aim of this study was to investigate students' perceptions of the use of social media networking systems during their time of studying at an open distance learning $(O D L)$ tertiary institution. The study also investigated whether students feel at ease when using social media networking systems, whether they will be able to find information on these social media networking systems, and whether they believe it will be an effective and easy way to study course content. These were tested by making use of the Technology Acceptance Model (TAM) constructs namely; 'Perceived ease of use', 'Perceived usefulness', 'Attitude towards using', and 'System accessibility'. A survey was distributed to students, and it was found that students regarded 'Perceived ease of use' as being the most important factor to consider when they are using social media networking systems.
\end{abstract}

Keywords: Open Distance Learning; ODL; Social Media; Social Media Networking Systems

\section{INTRODUCTION}

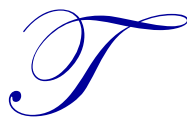

he past years have seen a revolution in the way education is delivered. The days of a one dimensional offering of knowledge to a passive audience, is long gone. Today's student is more informed and technology savvy than at any time in the past and with the advances in technology measured in days and not years, this pace of change is accelerating. The use of Internet-based social media networking systems have enabled companies, consumers, institutions and many more to communicate more effectively and in real time with hundreds, even thousands of other people around the world about a specific topic, product or issue at any point in time (Mangold \& Faulds, 2009: 357). Social media networking systems do not only make it easier for companies to communicate with their consumers, but also makes it easier for tertiary institutions to communicate related course work to their students, to encourage discussion between and among students and to address administrative issues (Adamson, 2012; Moran, Seaman \& Tinti-Kane, 2011: 4). Shen, Laffey, Lin and Huang (2006: 270) further indicate that online learning through means of various social media networking systems have become a very common educational format to use by both tertiary institutions and their students around the world, due to its flexibility of time and place. Social media networking systems have the ability to enable lecturers and students to collaborate and share information at any time convenient to them and from any place in the world (Adamson, 2012). 
Adamson (2012) is of the opinion that social media networking systems might change the focus of education from a single student to a group of students, but that students' individual learning experience is enhanced through collaboration and informal learning with their peers. However, according to Picardo (2011:1), it is a potential threat that the use of social media networking systems in the tertiary institution can lead to a loss of control for many lecturers as they experience social media networking systems as being highly disruptive. This may be attributed to the fact that students are more familiar with using different social media tools than the lecturers (Picardo, 2011:1).

King, Duke-Williams and Mottershead (in Picardo, 2011) are of the opinion that lecturers may resist the adoption of social media networking systems due to their lack of knowledge. This fact may have an impact on the use of social media networking systems in tuition and it is important to establish the wishes of the students in this regard.

\section{RESEARCH OBJECTIVES}

The purpose of this study is to determine students' perceptions on the use of social media networking systems during their time of studying at an open distance learning (ODL) tertiary institution. The following was specifically researched:

- To determine the perception of students on the effectivity of social media networking systems as a lecturing tool.

- To establish to what extent social media networking systems is utilised by students.

- To investigate the relationship between social media networking systems as a lecturing tool and the private use of social media networking systems by students.

The following section gives an overview of social media networking systems, the different types of social media networking systems, as well as a review of the influence thereof on students. The empirical findings and the discussion of the findings appears in the latter part of the paper.

\section{LITERATURE REVIEW}

\section{Overview of social media networking systems}

\section{Defining social media}

Social media is defined by Boyd and Ellison (2008:211) as, “... web-based services that allow individuals to construct a public or a semi-public profile within a bounded system, articulate a list of other users with whom they share a connection and view and traverse their list of connections and those made by others within the system". Mangold and Faulds (2009:357) on the other hand define social media or 'consumer-generated media' as, “... a variety of new sources of online information that are created, initiated, circulated and used by consumers intent on educating each other about products, brands, services, personalities and issues".

It is clear from these definitions that social media networking systems include various online, and word-ofmouth forums which also includes blogs, company-sponsored discussion boards and chat rooms, consumer-toconsumer email, consumer product or service ratings websites and forums, Internet discussion boards and forums, moblogs (sites containing digital audio, images, movies, or photographs), and social networking websites, to only name a few (Mangold \& Faulds, 2009:358).

According to Larson (2012) the five most popular social media networking systems used and accepted in the market are; Facebook with 901 million users, Twitter with 555 million users, Google+ with 170 million users, LinkedIn with 150 million users and lastly Pinterest with 11.7 million users. Given the importance and relevance of these different social media networking systems, a brief discussion of each is given below. 


\section{$\underline{\text { Facebook }}$}

Facebook is a social media networking system which was originally developed for tertiary students. Today it is open for any individual older than 13 years of age. Facebook enables their users to create and modify their own profiles with photos, videos and information about themselves. Facebook friends have the ability to browse the profiles of other friends, as well as write messages to them (Tech terms, 2008).

Facebook is a one-way communication form and it is a very effective tool to use for sharing information, as well as collaborating with students from a safe distance. Facebook groups do not require their members to be friends with each other and the members of the group can easily and immediately swap and upload files, links, articles, information and videos at no cost. A facebook page can, for example, be used as a central page for students and lecturers to share and discuss information (The Guardian, 2013).

\section{$\underline{\text { Twitter }}$}

Twitter is a micro-blogging application that can be described as a combination of instant messaging and blogging. It has established itself as an effective tool for communicating news, market trends, questions and answers, as well as sharing photos, videos and links with many benefits for both business and personal use (Social Media defined, 2008).

Some lecturers in tertiary institutions have managed to set-up subject or class Twitter accounts that students can follow. Lecturers can tweet information relevant to their subjects and they can even tweet homework or reading work to their students following them (The Guardian, 2013).

\section{$\underline{\text { Google+ }}$}

Google+ is a social networking system from Google that is presently an invitation-only service that offers functionality and many features that is comparable to Facebook (PCMAG, 2013). Google+ has developed and introduced Circles which is used to share information among different groups of people, Sparks which is used to offer videos and articles, and Hangouts which is used for video chatting with a friend or group of friends, together with other unique features (Webopedia, 2013).

According to WikiHow (n.d.), the many features (Circle, Sparks and Hangouts) that are offered by Google+ are of great value for lecturers teaching at institutions that are located at a distance from their students. The reason for this is that Google+ Hangouts is a tool that is created in order to reduce the travel-strain in the teaching processes. The time can then be used by lecturers to carry out more virtual classrooms at more places. Therefore Google+ enables institutions to teach more students with fewer lecturers, in that way saving costs, as well as placing institutions in a position to reward lecturers in more effective ways. The main benefit of Google+ Hangouts is that it enables lecturers to teach to ten classrooms simultaneously.

\section{$\underline{\text { LinkedIn }}$}

LinkedIn is a social networking website that is aimed at business professionals. It allows people to share work-related information with other users as well as to keep an online list of other professional contacts (WhatIs, 2013). LinkedIn also allow their users to create a profile page. The only difference is that a LinkedIn profile is created based on a business focus, instead of on a personal focus. In other words, a LinkedIn profile highlights education and past work experiences, almost the same as a resume. The profile also enables other users to see the connections list of each other, as well as the recommendations that are made to or received from other users (Tech Terms, 2010). 
$\underline{\text { Pinterest }}$

Pinterest is a social media website that enables users to organise and share images, quotes and videos from around the Web (Walker, 2013). Images that are uploaded by users/pinners are called Pins and can be organised into pinboards that are customised, themed and followed by other users. Users/pinners are allowed to like or repin images, videos and quotes that is shared by other users. Pinterest is very similar to Twitter, as any pinner/user can follow another (TechoPedia, 2013).

According to The Guardian (2013), Pinterest is becoming very popular as a virtual pinboard. It is a very effective way to share web resources that both students and lecturers might find interesting or relevant. Pinterest enables lecturers to make different pinboards by creating different categories that students can find useful and the other way around.

Youtube

YouTube is a video sharing service that enables users to watch videos that are posted by other users, as well as upload their own videos. All uploaded videos on YouTube appear on the YouTube website and can also be posted on other websites, although the original files are hosted on the YouTube server (PCMAG, 2013).

The YouTube service was originally designed for ordinary people who want to publish videos that they have created themselves. However, a number of companies and organisations also use YouTube to promote their businesses (Tech Terms, 2009). People also use YouTube to post instructional videos for instance step-by-step and do-it-yourself guides, educational information lessons, power point presentations and other how-to videos (Tech Terms, 2009).

According to Adamson (2012) social media networking systems are an important tool for learning and should be used for this purpose more extensively. Due to the fact that both students and some lecturers are familiar with social media networking systems they should take advantage of this and use social media networking systems as a platform for communication, learning and collaboration, as well as sharing ideas and topics of interest (Adamson, 2012). In order to use social media networking systems effectively both lecturers and students should be aware of the benefits of social media networking systems. By doing this, it will enable them to communicate with each other on a more effective, flexible and faster way (Laffey et al., 2006: 270).

\section{The use and benefits of social media networking systems}

According to Jackson (2011), the use of social media networking systems in classrooms can have a positive psychological effect on students. As soon as students were allowed to answer questions by means of using, for example Twitter, they felt less pressured even though the answer was wrong.

Table 1 below summarises the ways in which social media networking systems can be implemented in teaching, as well as the benefits thereof. 
Table 1: Uses and benefits of social media networking systems

\begin{tabular}{|c|c|}
\hline $\begin{array}{c}\text { Type of } \\
\text { Social } \\
\text { Media } \\
\text { System } \\
\end{array}$ & Description of use and benefits \\
\hline Facebook & $\begin{array}{l}\text { - Improve communication by enabling students to easily contact lecturers and other students with questions. } \\
\text { - } \quad \text { Easily integrate class projects with facebook through the sharing of books, reviews and promoting student } \\
\text { work. } \\
\text { - Use facebook applications and groups in order to make learning and studying easier and more enjoyable } \\
\text { for students. } \\
\text { - Create a Facebook page where you can schedule events, post notes and remind students of important dates } \\
\text { and due dates. }\end{array}$ \\
\hline Twitter & $\begin{array}{l}\text { Post additional materials such as links to articles and videos in order for students to continue with their } \\
\text { learning even if classes are over. } \\
\text { - Setting-up specific feeds to enable all students to see and monitor certain events. } \\
\text { Develop a feed for your students in order to tweet about important dates, upcoming events and } \\
\text { assignments, as well as class news. } \\
\text { - } \quad \text { Connect with other students, lecturers, as well as parents in order to increase communication and build } \\
\text { community. } \\
\text { Follow tweets of other lecturers' in order to keep up with the latest teaching trends, to get ideas and to } \\
\text { - } \quad \text { Shapport one another. }\end{array}$ \\
\hline Pinterest & $\begin{array}{l}\text { - Use community boards for group projects, as well as brainstorming to enable a number of users to save } \\
\text { their resources in one place. } \\
\text { - } \quad \text { Allow and encourage students to use Pinterest for presentations and projects. } \\
\text { - Search for inspiring tips on how to organise and decorate your classroom. } \\
\text { - } \quad \text { Search, find, pin and organise images, projects, videos, stories etc for future classes and projects. }\end{array}$ \\
\hline YouTube & $\begin{array}{l}\text { - Search for video-clips under specific topics that can be used in the classroom to give a lesson in a more } \\
\text { memorable way. } \\
\text { - } \quad \text { Organise playlists to enable students to easily find and watch all relevant and approved videos on a topic. } \\
\text { - } \quad \text { Record lessons and post them on YouTube in order for students to review them whenever they want to. } \\
\text { - Create interactive videos by adding quizzes, comments etc to it. }\end{array}$ \\
\hline
\end{tabular}

Source: Lepi, K. 2012. 25 Ways teachers can integrate social media into education. [Online] Available from:

http://edudemic.com/2012/07/a-teachers-guide-to -social-media/ [Accessed: 13-02-2013].

According to Picardo (2011) students' perceptions and use of technology will play a part in the use or absence of social media networking systems in tertiary institutions. The question still to be answered is; 'Do students wish to interact with their lecturers online'? The answer to this question may be more complex than it initially appears to be, as the participation of students in a social media networking system should be voluntary in order to ensure that the necessary quality of interaction and cooperation is obtained in order to improve teaching and learning (Picardo, 2011).

Picardo (2011) further argues that social media networking systems challenge the ability of both lecturers and students to interact and collaborate successfully via this medium, meaning that when it comes to academia students do not feel comfortable with the degree of transparency needed in order for the social media networking systems to be effective.

In order to determine the students' perceptions on the use of social media networking systems in tertiary institutions (higher education), the five constructs of the Technology Acceptance Module was studied. These are discussed in the next section. 


\section{Technology Acceptance Model}

The Technology Acceptance Model (TAM) is an information system (a system that consists of all the network communication channels used within an organisation) theory that demonstrates how users accept and use specific technology (Davis, 1993:475). The model indicates that when users are confronted with a new software package, various factors influence their decision about how and when they will use this specific technology (Mazhar, 2006). Davis, Bagozzi and Warshaw (1989:985) indicated that user motivation can be explained by three constructs; 'Perceived ease of use', 'Perceived usefulness', and 'Attitude toward using the system'.

The first construct is 'Perceived usefulness' which is described according to Davis (1993:477) as, “... the degree to which an individual believes that using a particular system would enhance his or her job performance". The second construct which is 'Perceived ease of use' is defined as, "... the degree to which an individual believes that using a particular system would be free from effort" (Davis, 1993:477). The third construct is "Attitude towards using' and is defined as, "... the degree of evaluative affect that an individual associates with using the target the target system in his or her job". The last construct that was being tested, was that of 'System accessibility' which refers to organisational context variables.

These constructs were imbedded in the research study. The next section deals with the research methodology and the findings of the research.

\section{RESEARCH METHODOLOGY}

In determining the perceptions of students on social media networking systems, a questionnaire was developed for this study. The questionnaire mostly incorporated questions that are of a quantitative nature. A total of 221 correctly completed questionnaires were obtained.

The demographic profile of the respondent group is presented in Table 2 below. The majority of students (29.80 per cent) were between 18 and 24 years of age. The gender split for the respondent group is female dominated, with 63 per cent of the students being female. Most of the respondents are African (62.63 per cent).

Table 2: Demographic profile

\begin{tabular}{|c|c|c|}
\hline Age group & \% of Total & N \\
\hline $18-24$ & $29.80 \%$ & 59 \\
\hline $25-29$ & $25.25 \%$ & 50 \\
\hline $30-34$ & $17.68 \%$ & 35 \\
\hline $35-39$ & $15.66 \%$ & 31 \\
\hline $40+$ & $11.62 \%$ & 23 \\
\hline \multicolumn{3}{|c|}{ Gender } \\
\hline Male & $37.00 \%$ & 74 \\
\hline Female & $63.00 \%$ & 126 \\
\hline African & Race & 119 \\
\hline Coloured & $62.63 \%$ & 36 \\
\hline Indian & $18.95 \%$ & 9 \\
\hline White & $4.74 \%$ & 26 \\
\hline
\end{tabular}

\section{RESEARCH FINDINGS}

\section{Perceptions of students on social media networking systems as a lecturing tool}

To determine the perceptions students had of social media networking systems, respondents were asked to rate 21 statements on a seven point Likert scale ( 1 being "Strongly disagree" and 7 being "Strongly agree"). 
The 21 statements are structured as five sub-constructs:

- $\quad$ 'Perceived ease of use': statements 1 to 5

- $\quad$ 'Perceived usefulness': statements 6 to 10

- $\quad$ 'Attitude towards using': statements 11 to 15

- $\quad$ 'Intention to use': statements 16 to 20

- $\quad$ 'System accessibility': statement 21

Table 3 below represents the first construct- 'Perceived ease of use'.

Table 3: 'Perceived ease of use'

\begin{tabular}{|c|c|c|c|c|c|c|c|c|c|}
\hline & & \begin{tabular}{l|} 
Strongly \\
Disagree \\
\end{tabular} & 2 & 3 & 4 & 5 & 6 & \begin{tabular}{|c|}
$\begin{array}{c}\text { Strongly } \\
\text { Agree }\end{array}$ \\
\end{tabular} & Mean \\
\hline & & \multicolumn{7}{|c|}{$\%$ of Total } & \\
\hline 1 & $\begin{array}{l}\text { Social network systems is easy to } \\
\text { use }\end{array}$ & $12.89 \%$ & $6.19 \%$ & $7.22 \%$ & $10.82 \%$ & $8.76 \%$ & $13.40 \%$ & $40.72 \%$ & 4.99 \\
\hline 2 & $\begin{array}{l}\text { Easy learning to use social } \\
\text { network systems }\end{array}$ & $11.34 \%$ & $4.64 \%$ & $7.22 \%$ & $11.86 \%$ & $9.28 \%$ & $15.98 \%$ & $39.69 \%$ & 5.10 \\
\hline 3 & $\begin{array}{l}\text { Interaction with social network } \\
\text { systems is clear and } \\
\text { understandable }\end{array}$ & $10.94 \%$ & $6.25 \%$ & $6.77 \%$ & $14.58 \%$ & $10.42 \%$ & $17.19 \%$ & $33.85 \%$ & 4.94 \\
\hline 4 & $\begin{array}{l}\text { Easy to find information on social } \\
\text { network systems }\end{array}$ & $10.42 \%$ & $8.33 \%$ & $4.17 \%$ & $14.06 \%$ & $13.54 \%$ & $17.19 \%$ & $32.29 \%$ & 4.93 \\
\hline 5 & $\begin{array}{l}\text { Easy to become skilful at using } \\
\text { social network systems }\end{array}$ & $8.81 \%$ & $7.77 \%$ & $5.18 \%$ & $15.03 \%$ & $16.58 \%$ & $13.99 \%$ & $32.64 \%$ & 4.95 \\
\hline
\end{tabular}

Most respondents agreed or strongly agreed with the statements by marking 5, 6 or 7, this is also shown by the averages varying from 4.93 to 5.10, although few respondents strongly disagreed. All the measurements of perceived ease of use' were agreed upon by the respondents. Considering the averages (for ranking purposes) the mostly agreed upon item is the item 'Learning to use social networking systems would be easy for me'.

The following share chart produces a visual representation of the responses with red agreeing and blue disagreeing.

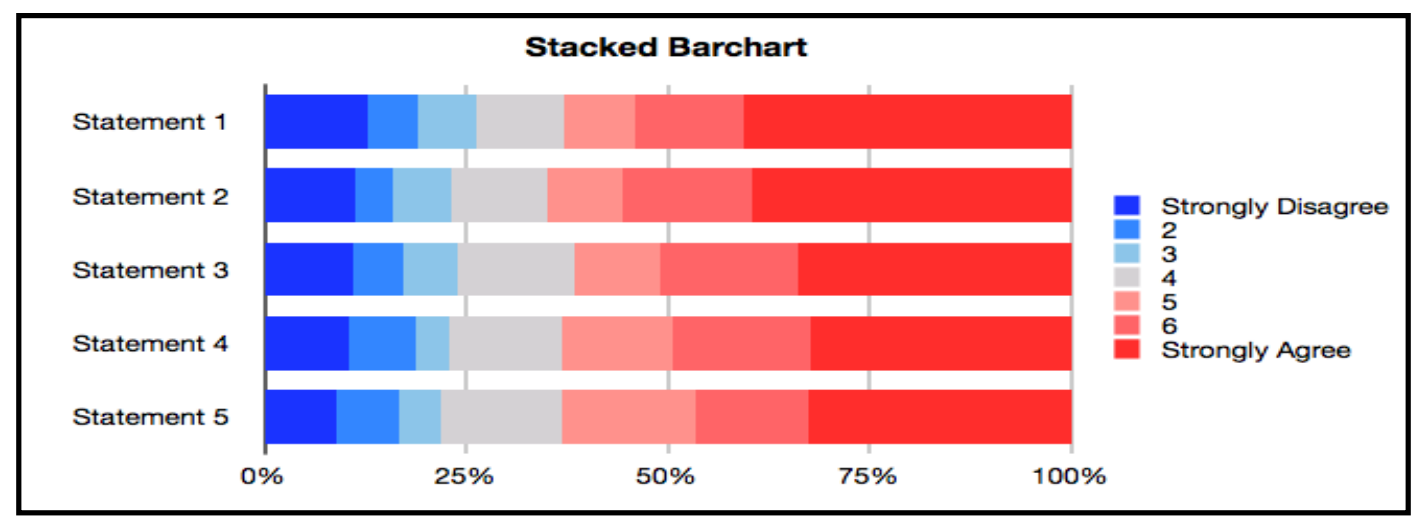

Figure 1: 'Perceived ease of use' responses 
Table 4 below represents the second construct - 'Perceived usefulness'.

Table 4: 'Perceived usefulness'

\begin{tabular}{|c|c|c|c|c|c|c|c|c|c|}
\hline & & $\begin{array}{l}\text { Strongly } \\
\text { Disagree }\end{array}$ & 2 & 3 & 4 & 5 & 6 & $\begin{array}{c}\text { Strongly } \\
\text { Agree }\end{array}$ & Mean \\
\hline & & \multicolumn{7}{|c|}{$\%$ of Total } & \\
\hline 6 & $\begin{array}{l}\text { Using social network systems would } \\
\text { enhance effectiveness in teaching }\end{array}$ & $11.52 \%$ & $7.85 \%$ & $10.47 \%$ & $14.14 \%$ & $15.71 \%$ & $15.71 \%$ & $24.61 \%$ & 4.60 \\
\hline 7 & $\begin{array}{l}\text { Using social network systems would } \\
\text { improve course performance }\end{array}$ & $14.14 \%$ & $7.33 \%$ & $8.38 \%$ & $19.37 \%$ & $13.09 \%$ & $14.14 \%$ & $23.56 \%$ & 4.47 \\
\hline 8 & $\begin{array}{l}\text { Using social network systems would } \\
\text { increase my productivity in my } \\
\text { teaching work }\end{array}$ & $16.93 \%$ & $5.82 \%$ & $8.99 \%$ & $18.52 \%$ & $15.34 \%$ & $11.11 \%$ & $23.28 \%$ & 4.36 \\
\hline 9 & $\begin{array}{l}\text { I found social network systems } \\
\text { useful }\end{array}$ & $14.52 \%$ & $7.53 \%$ & $4.30 \%$ & $14.52 \%$ & $11.29 \%$ & $17.74 \%$ & $30.11 \%$ & 4.74 \\
\hline 10 & $\begin{array}{l}\text { Social network systems could make } \\
\text { it easier to study course content }\end{array}$ & $18.03 \%$ & $7.65 \%$ & $8.74 \%$ & $17.49 \%$ & $14.21 \%$ & $13.11 \%$ & $20.77 \%$ & 4.25 \\
\hline
\end{tabular}

Most respondents agreed with the statements by marking 5,6 or 7 , this is also shown by the averages varying from 4.25 to 4.74 , although some respondents strongly disagreed. The respondents agreed upon all the measurements of 'perceived usefulness'. Considering the averages (for ranking purposes) the mostly agreed upon item is 'I found social network systems useful', while the item 'Social network systems could make it easier to study course content' were least agreed upon.

The following share chart produces a visual representation of the responses with red agreeing and blue disagreeing.

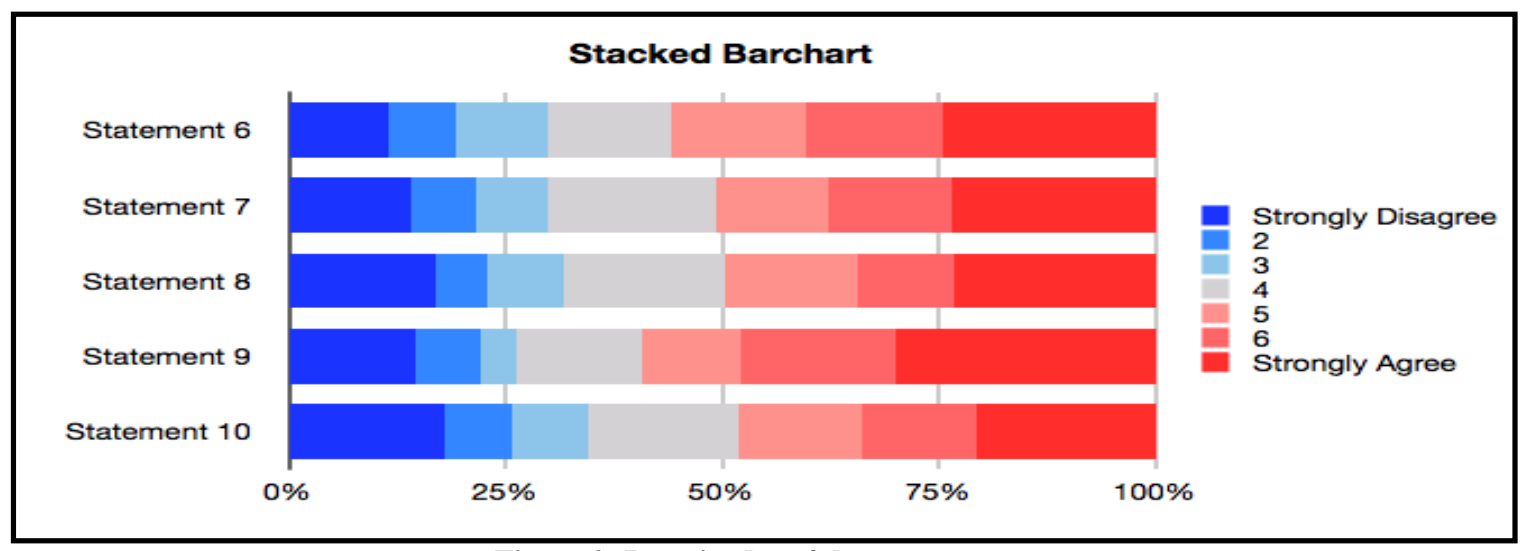

Figure 2: Perceived usefulness responses 
Table 5 below represents the third construct - 'Attitude towards using social media'.

Table 5: 'Attitude towards using social media'

\begin{tabular}{|c|c|c|c|c|c|c|c|c|c|}
\hline & & $\begin{array}{l}\text { Strongly } \\
\text { Disagree }\end{array}$ & 2 & 3 & 4 & 5 & 6 & $\begin{array}{c}\text { Strongly } \\
\text { Agree }\end{array}$ & Mean \\
\hline & & \multicolumn{7}{|c|}{$\%$ of Total } & \\
\hline 11 & $\begin{array}{l}\text { Disliking the idea of using social } \\
\text { network systems }\end{array}$ & $16.40 \%$ & $8.99 \%$ & $5.82 \%$ & $10.05 \%$ & $10.05 \%$ & $12.70 \%$ & $35.98 \%$ & 4.70 \\
\hline 12 & $\begin{array}{l}\text { Favourable attitude towards using } \\
\text { social network systems }\end{array}$ & $18.92 \%$ & $5.95 \%$ & $7.03 \%$ & $18.38 \%$ & $14.05 \%$ & $13.51 \%$ & $22.16 \%$ & 4.32 \\
\hline 13 & $\begin{array}{l}\text { Good idea to use social network } \\
\text { systems for teaching }\end{array}$ & $17.84 \%$ & $9.19 \%$ & $6.49 \%$ & $15.14 \%$ & $14.59 \%$ & $12.43 \%$ & $24.32 \%$ & 4.34 \\
\hline 14 & $\begin{array}{l}\text { Using social network systems is a } \\
\text { foolish idea }\end{array}$ & $12.23 \%$ & $4.79 \%$ & $3.19 \%$ & $11.17 \%$ & $11.70 \%$ & $9.04 \%$ & $47.87 \%$ & 5.24 \\
\hline 15 & $\begin{array}{l}\text { Positive towards social network } \\
\text { systems }\end{array}$ & $17.74 \%$ & $4.30 \%$ & $7.53 \%$ & $10.22 \%$ & $15.59 \%$ & $16.67 \%$ & $27.96 \%$ & 4.63 \\
\hline
\end{tabular}

Please note that items Question 13.11 and Question 13.14 were reversed. Most respondents agreed with the statements by marking 5,6 or 7 , this is also shown by the averages varying from 4.32 to 5.24 , although some respondents strongly disagreed. The respondents agreed upon all the measurements of 'Attitude towards social media use'. Considering the averages (for ranking purposes) the mostly agreed upon item is 'Using social network systems is (NOT) a foolish idea', while the item 'I have a generally favourable attitude towards using social network systems' were least agreed upon.

The following share chart produces a visual representation of the responses with red agreeing and blue disagreeing.

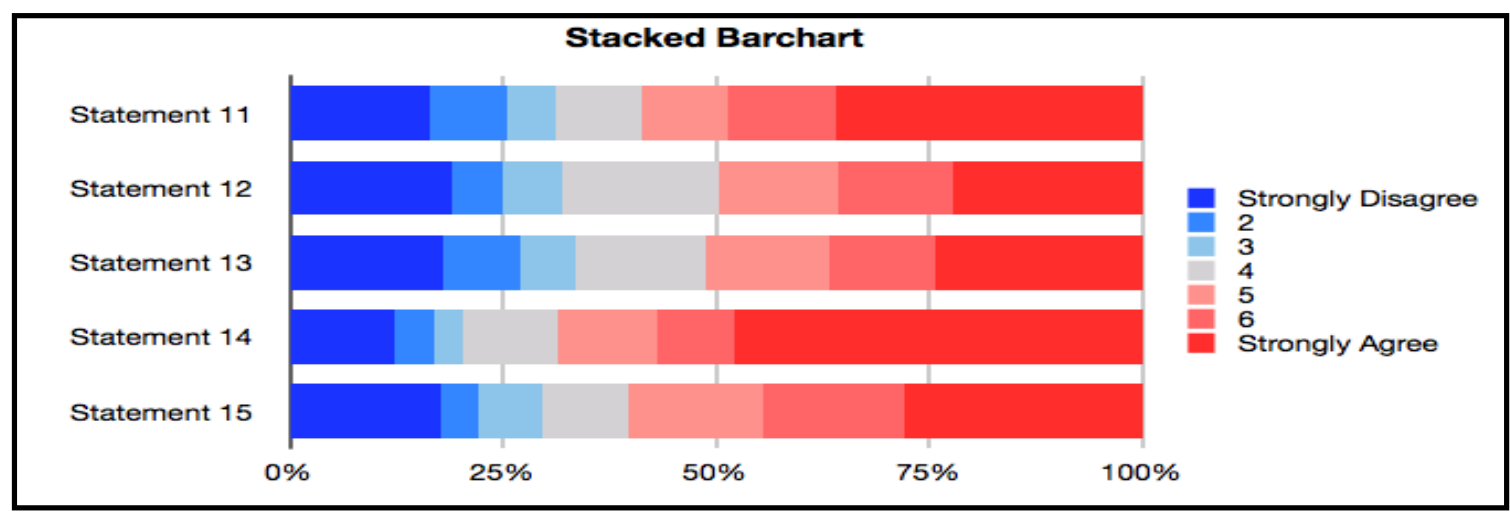

Figure 3: Attitude towards using social media responses 
Table 6 below represents the fourth construct - 'Intention to use social media'.

Table 6: Intention to use social media

\begin{tabular}{|l|l|c|c|c|c|c|c|c|c|c|}
\hline & $\begin{array}{c}\text { Strongly } \\
\text { Disagree }\end{array}$ & $\mathbf{2}$ & $\mathbf{3}$ & $\mathbf{4}$ & $\mathbf{5}$ & $\mathbf{6}$ & $\begin{array}{c}\text { Strongly } \\
\text { Agree }\end{array}$ & \begin{tabular}{c} 
Mean \\
\hline
\end{tabular} & \multicolumn{7}{|c|}{$\%$ of Total } & \multicolumn{5}{|c|}{ \% } \\
\hline 16 & $\begin{array}{l}\text { Intend to use social network systems } \\
\text { for teaching purposes }\end{array}$ & $18.18 \%$ & $6.42 \%$ & $7.49 \%$ & $19.25 \%$ & $12.83 \%$ & $14.44 \%$ & $21.39 \%$ & 4.31 \\
\hline 17 & $\begin{array}{l}\text { Often return to social network } \\
\text { systems }\end{array}$ & $15.76 \%$ & $4.89 \%$ & $8.70 \%$ & $20.65 \%$ & $10.87 \%$ & $10.87 \%$ & $28.26 \%$ & 4.52 \\
\hline 18 & $\begin{array}{l}\text { Intend to visit social network systems } \\
\text { frequently for teaching work }\end{array}$ & $15.96 \%$ & $5.32 \%$ & $9.04 \%$ & $13.83 \%$ & $16.49 \%$ & $14.89 \%$ & $24.47 \%$ & 4.52 \\
\hline 19 & $\begin{array}{l}\text { Intend to be a heavy user of social } \\
\text { network systems }\end{array}$ & $18.52 \%$ & $6.88 \%$ & $12.17 \%$ & $17.46 \%$ & $12.70 \%$ & $11.11 \%$ & $21.16 \%$ & 4.17 \\
\hline 20 & $\begin{array}{l}\text { Intend to use social network systems } \\
\text { for communication }\end{array}$ & $13.37 \%$ & $6.95 \%$ & $7.49 \%$ & $11.23 \%$ & $14.97 \%$ & $9.63 \%$ & $36.36 \%$ & 4.82 \\
\hline
\end{tabular}

Most respondents agreed with the statements by marking 5,6 or 7 , this is also shown by the averages varying from 4.17 to 4.82 , although some respondents strongly disagreed. All the measurements of 'intention to use' were agreed upon by the respondents. Considering the averages (for ranking purposes) the mostly agreed upon item is 'I intend to use social network systems for communicating with others', while the item 'I intend to be a heavy user of social network systems' were least agreed upon.

The following share chart produces a visual representation of the responses with red agreeing and blue disagreeing.

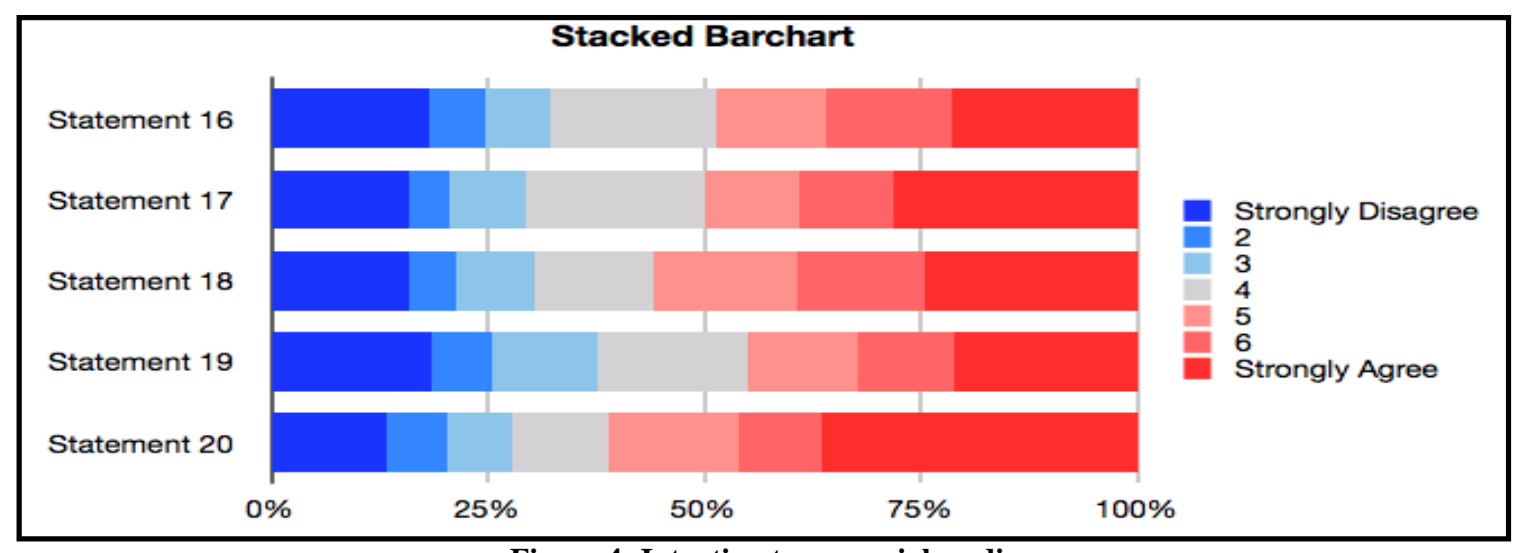

Figure 4: Intention to use social media

Table 7 below represents the fifth construct - 'System accessibility'.

Table 7: 'System accessibility'

\begin{tabular}{|l|l|c|c|c|c|c|c|c|c|}
\hline & & $\begin{array}{l}\text { Strongly } \\
\text { Disagree }\end{array}$ & $\mathbf{2}$ & $\mathbf{3}$ & $\mathbf{4}$ & $\mathbf{5}$ & $\begin{array}{c}\text { 6 } \\
\text { Strongly } \\
\text { Agree }\end{array}$ \\
\hline & \multicolumn{7}{|c|}{ \% of Total } \\
\hline 21 & $\begin{array}{l}\text { No difficulty accessing and using an e- } \\
\text { learning system }\end{array}$ & $12.50 \%$ & $5.43 \%$ & $8.15 \%$ & $10.33 \%$ & $15.22 \%$ & $14.67 \%$ & $33.70 \%$ \\
\hline
\end{tabular}

Most respondents agreed with the statement 'I have no difficulty accessing and using an e-learning system in the university' by marking 5, 6 or 7 . The average for ranking purposes is 4.89 . 


\section{Reliability of the sub-constructs}

Reliability is the consistency of the measurement, or the degree to which an instrument measures the same way each time it is used under the same condition with the same subjects. A Cronbach's alpha value above 0.8 has a very good reliability, a value between 0.6 and 0.8 has an acceptable reliability and a value below 0.6 has an unacceptable reliability. The Cronbach's alpha for the four sub-constructs all yielded high Cronbach's alpha values $(\geq 0.80)$ indicating good reliability. Table 8 below represents the Cronbach's alpha values of each of the five subconstructs. Please note that 'Accessibility' is only one item and cannot be tested for reliability.

Table 8: Cronbach's alpha

\begin{tabular}{|c|c|c|}
\hline Sub-construct & Questions & Cronbach's alpha \\
\hline Ease of use score & Statements 1 to 5 & 0.92 \\
\hline Usefulness score & Statements 6 to 10 & 0.92 \\
\hline Attitude score & Statements 11 to 15 & 0.80 \\
\hline Intention score & Statements 16 to 20 & 0.91 \\
\hline Accessibility score & Statement 21 & None \\
\hline
\end{tabular}

The individual Cronbach's Coefficient Alpha value of each dimension is used as a measure of the reliability of the tested dimension. A reliable Cronbach's Coefficient Alpha value validates that the individual items of a dimension measured the same dimension (concept) in the same manner (or consistently). For each subconstruct a mean was calculated to assess the level of agreement among sub-constructs. Table 9 below shows the means and standard deviations.

Table 9: Means and standard deviation

\begin{tabular}{|c|c|c|}
\hline Sub-construct & Mean & Standard Deviation \\
\hline Ease of use score & 4.98 & 1.80 \\
\hline Usefulness score & 4.50 & 1.84 \\
\hline Attitude score & 4.64 & 1.65 \\
\hline Intention score & 4.44 & 1.84 \\
\hline Accessibility score & 4.89 & 2.10 \\
\hline
\end{tabular}

The sub-construct 'Ease of use' was considered most important with a mean of 4.98, while 'Intention' was least important with a mean of 4.44. However, the means were closely distributed, indicating a general agreement on the importance of all the sub-constructs, but not strong.

The standard deviations are fairly high indicating variation in agreement among sub-constructs.

\section{Profiling the views of respondents on social media networking systems}

The biographical variables age, gender and population group were tested against the sub-constructs for significant different views. Of the biographical variables tested, only age groups showed significant different views.

\section{Comparison of the respondents views on the five sub-constructs of social media use among age groups}

A profile plot from Multivariate Analysis of Variance (MANOVA) will be used in order to explore differences between the different sub-constructs mean score's of students of different age groups. The profile plots from the MANOVA shows the least square means. 


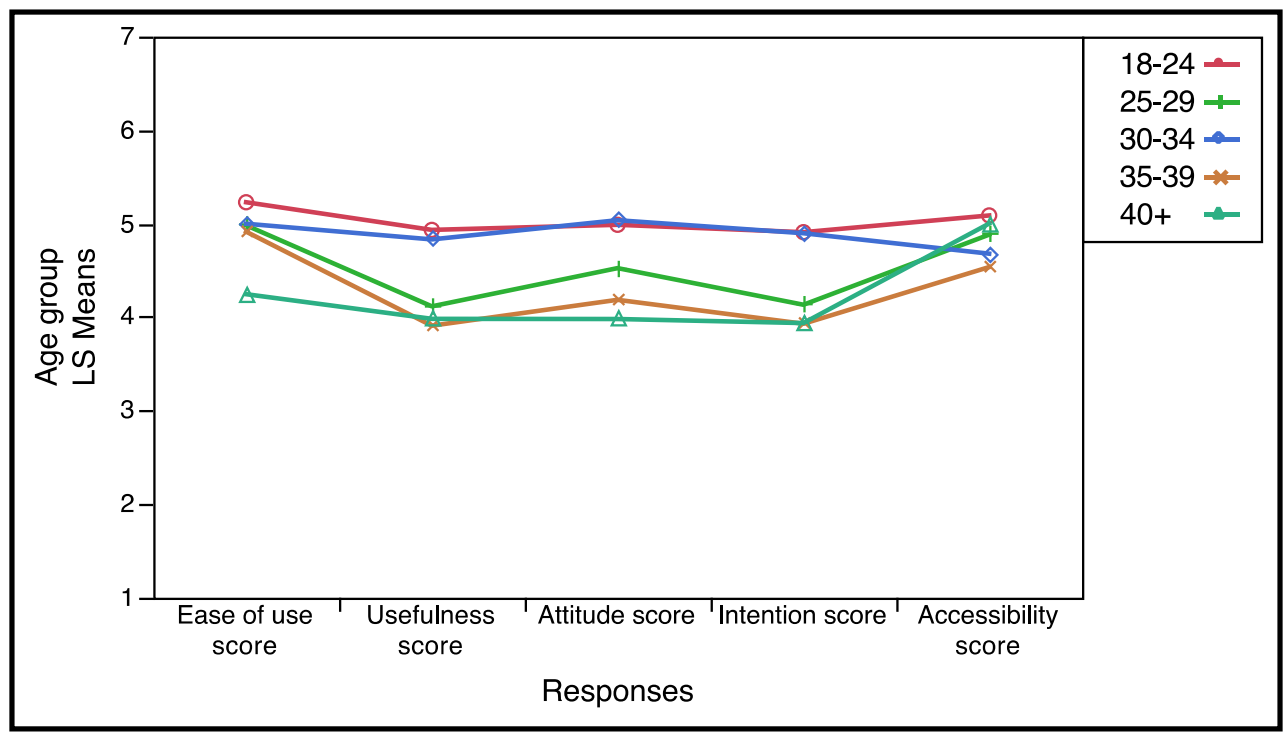

Figure 5: Students of different age groups on five social media sub-constructs

From the figure it is clear that there is a difference between some of the age groups. The age-groups 18-24 years and 30-34 years seemed to view the sub-constructs of social media more important than the rest of the agegroups.

In order to develop a profile of the different age groups, the following descriptive statistics should be taken into consideration, as observed from the table below.

Table 10: Descriptive statistics of age groups

\begin{tabular}{|c|c|c|c|c|c|}
\hline Age group & Ease of use score & Usefulness score & Attitude score & Intention score & Accessibility score \\
\hline $18-24$ & 5.23 & 4.93 & 4.99 & 4.91 & 5.09 \\
\hline $25-29$ & 4.98 & 4.11 & 4.52 & 4.13 & 4.88 \\
\hline $30-34$ & 5.00 & 4.83 & 5.04 & 4.90 & 4.68 \\
\hline $35-39$ & 4.91 & 3.91 & 4.19 & 3.93 & 4.54 \\
\hline $40+$ & 4.25 & 3.98 & 3.98 & 3.94 & 5.00 \\
\hline
\end{tabular}

From the table it is clear that the 18-24 years and 30-34 years age groups have higher scores on 'Usefulness' (4.93 and 4.83), 'Attitude' (4.99 and 5.04) and 'Intention' (4.91 and 4.90) than the other age groups.

In order to determine whether these differences between the means of the age-groups are statistically significant, separate Analysis of Variance (ANOVA) were conducted for each sub-construct. The distributions of the constructs were tested for normality. Because the sub-constructs were not normally distributed nonparametric Kruskall Wallis tests was used instead of ANOVA.

From the Kruskall Wallis analyses probability values (p-values) were produced. A 'p-value' smaller than 0.05 indicates a significant difference between the means of the dimension tested for the spectator groups at a 95per cent level of confidence.

Only significant differences are shown in table 11 below.

Table 11: Significant differences

\begin{tabular}{|c|c|c|c|c|}
\hline Sub-construct & Chi-Square value & DF & P-value & Significance \\
\hline Usefulness & 10.36 & 4 & 0.0348 & Significant \\
\hline Attitude & 9.79 & 4 & 0.0442 & Significant \\
\hline Intention to use & 9.09 & 4 & 0.0589 & Borderline case \\
\hline
\end{tabular}


Significant differences between the age-groups exist for the sub-constructs 'Usefulness' and 'Attitude' at a 95 per cent level of confidence, while 'Intention to use' is significant at a 90per cent level of confidence.

\section{CONCLUSION}

Due to the fact that technology changes daily, people, specifically students, are more enabled to become informed and aware of the different types of technological systems as opposed to a few years ago. The use of the internet has further enabled many people, students and institutions around the world to communicate more effectively with each other on specific topics and issues at any point in time (Mangold \& Faulds, 2009: 357). Therefore, it becomes evident that the use of social media networking systems among tertiary institutions does not only make communication easier between them and the students, but it can also add a lot of value in encouraging discussions between and among students, as well as addressing administrative issues (Moran, Seaman \& Tinti-Kane, 2011: 4; Adamson, 2012).

The findings of the study revealed that the most important factors according to the students' perceptions of the effectiveness of social media networking systems as a lecturing tool was; 'Ease of use' and 'Accessibility'. It is clear that social media networking systems can easily be adopted as an educational tool, as learners are exposed to social media networking systems in a social application. Although, social media networking systems are regarded as useful, there is a degree of doubt that it could ease up the learning process. It is clear according to the findings that using social media networking systems for educational purposes is not a foolish idea and that students would like to use social media networking systems to communicate with fellow students, lecturers; discussion forums etc. The responsiveness and application of social media networking systems makes it an ideal instrument for real time communication.

When analysing the constructs and by taking demographic information into consideration, no significant biographical differences were found, except for age-groups. The age-groups 18-24 years and 30-34 years seemed to view the sub-constructs of social media networking systems as more important than the rest of the age-groups.

The findings revealed that social media networking systems are used more for social purposes than it is for work purposes, and it is used between 0 and 5 hours per week. Facebook is the most used social media application. Furthermore, the age-group 40+ used Facebook significantly less than the other age-groups.

When analysing the relationship between perceptions of social media networking systems and use of social media networking systems, the findings revealed that the users of social media networking systems considered all the constructs as more important than the none users of social media networking systems. The constructs 'Ease of use', 'Attitude', 'Intention to use' and 'Accessibility' were significantly more important for the none users of social media networking systems.

It was found that younger age groups generally put more importance on the use of social media networking systems, while students that do not use social media networking systems put less emphasis on it. It is therefore recommended that tertiary institutions make social media networking systems for educational purposes more attractive by implementing programmes to stimulate usage, especially under older students. The type of social media networking systems used should be easy to use, as well as accessible.

\section{AUTHOR INFORMATION}

Prof. Jan Wiid is an Associate Professor in the Department of Marketing and Retail Management at the University of South Africa (UNISA). He has published 6 articles in refereed journals and is the editor and author of more than 5 books in marketing. These books are widely prescribed at universities in South Africa. He holds a DCom in Marketing from the University of Johannesburg. Prof. Jan Wiid, DCom, University of South Africa (UNISA), Department of Marketing and Retail Management, P.O. Box 329, UNISA, 0003. E-mail: jwiid@unisa.ac.za 
Prof Michael Cant is the CoD of the Department of Marketing and Retail Management at the University of South Africa (UNISA). He has published over 40 accredited articles in refereed journals and is the editor and author of more than 30 books in marketing. These books are widely prescribed at universities in South Africa. He has presented papers at more than 45 international conferences all over the world and is a well respected marketing and retail scholar. He holds a PhD in Marketing from the University of South Africa. Prof. Michael C. Cant, Ph.D., University of South Africa (UNISA), Department of Marketing and Retail Management, P.O. Box 329, UNISA, 0003 South Africa. E-mail: cantmc@ unisa.ac.za (Corresponding author)

Corinne Nell is a lecturer in the Department of Marketing and Retail Management at the University of South Arica (UNISA). She worked in the retail sector in South Africa for many years and therefore developed an interest in retailing. Academic interests include retailing with a specific focus on Visual merchandising and store atmospherics, consumer behaviour, social media and consumers' perception. Corinne Nell, University of South Africa (UNISA), Department of Marketing and Retail Management, P.O. Box 329, UNISA, 0003 South Africa. E-mail: nellec@unisa.ac.za

\section{REFERENCES}

1. Adamson, C. (2012). The Role of Social Media in Education. Retrieved from: http://www.icwe.net/oeb special/OEB Newsportal/the-role-of-social-and-mobile-media-in-education/

2. Borges, B. (2012). 40 Year History of Social media Infographic Poster. Retrieved from: http://www.findandconvert.com/2012/02/40-year-history-of-social-media/

3. Boyd, D.M. \& Ellison, N.B. (2008). Social Network Sites: Definition, History, and Scholarship. Journal of computer-mediated communication, 13: 210-230.

4. Davis, F.D. (1993). User acceptance of information technology: System characteristics, user perceptions and behavioural impacts. Academic Press Limited, 38: 475-487.

5. Hobbs, R. (2004). A Review of School-Based Initiatives in Media Literacy education. American Behavioural Scientist, 48(1): 42-59.

6. Jackson, C. (2011). Teaching Tolerance: Your students love social media and so can you. Retrieved from: http://www.tolerance.org/magazine/number-39-spring-2011/feature/your-students-love-social-media-andso-can-you

7. Larson, D. (2012). Infographic: Spring 2012 Social Media user Statistics. Retrieved from: http://blog.tweetsmarter.com/social-media/spring-2012-social-media-user-statistics/

8. Lepi, K. (2012). 25 Ways teachers can integrate social media into education. Retrieved from: http://edudemic.com/2012/07/a-teachers-guide-to -social-media/ [Accessed: 13-02-2013].

9. Mangold, W.G. \& Faulds, D.J. (2009). Social Media; The new hybrid element of the promotion mix. Business horizons, 52:357-365.

10. Mazhar, N. (2006). Technology Acceptance Model. Retrieved from: http://ezinearticles.com/?TechnologyAcceptance-Model\&id $=202354$

11. Moran, M., Seaman, J. \& Tinti-Kane, H. (2011). Teaching, Learning and Sharing: How today’s higher education faculty use social media. Retrieved from: http://www.pearsonlearningsolutions.com/educators/pearson-social-media-survey-2011-bw.pdf

12. Park, S.Y. (2009). An Analysis of the Technology Acceptance Model in Understanding University Students' Behavioural Intention to Use e-Learning. Educational Technology \& Society, 12(3): 150-162.

13. PCMAG. (2013). Google+. Retrieved from: http://www.pcmag.com/encyclopedia term/0,1237,t=Google\&i=63547,00.asp

14. PCMAG. (2013). YouTube. [Online] Available from: http://www.pcmag.com/encyclopedia term/0,1237,t=YouTube\&i=57119,00.asp

15. Picardo, J. (2011). Teaching and Learning with Social Networks: barriers to Adoption. Retrieved from: http://www.josepicardo.com/2011/08/teaching-and-learning-with-social-networks-barriers-to-adoption/

16. Shen, D., Laffey, J., Lin, Y. \& Huang, X. (2006). Social Influence for Perceived Usefulness and Ease-ofUse of Course Delivery Systems. Journal of Interactive Online Learning, 5(3):270-282.

17. Social Media Defined. (2008). Twitter defined. Retrieved from: http://www.socialmediadefined.com/2008/11/19/twitter-defined/ 
18. Tech Terms. (2008). Facebook. Retrieved from: http://www.techterms.com/definition/facebook

19. Tech Terms. (2009). YouTube. Retrieved from: http://www.techterms.com/definition/youtube

20. Tech Terms. (2013). LinkedIn. Retrieved from: http://www.techterms.com/definition/linkedin

21. Techopedia. (2013). Pinterest. Retrieved from: http://www.techopedia.com/definition/28407/pinterest

22. The Guardian. (2013). Social Media for Schools: A guide to Twitter, Facebook and Pinterest. Retrieved from: http://www.guardian.co.uk/teacher-network/2012/jul/26/social-media-teacher-guide

23. Venkatesh, V. \& Davis, F.D. (2000). A theoretical Extension of the Technology Acceptance Model: Four longitudinal field studies. Management Science, 46(2): 186-204.

24. Walker, L. (2013). Pinterest Definition - What is Pinterest.com? Retrieved form: http://personalweb.about.com/od/contentsharing/a/Pinterest-Definition.htm

25. Web Tips. (2012). 5 Types of social media users to interact well. Retrieved from: http://web-tipsonline.blogspot.com/2012/12/5-Types-of-Social-Media-Users-to-Interact-Well.html

26. Webopedia. (20130. Google+ (Google Plus). Retrieved from: http://www.webopedia.com/TERM/G/google-google-plus.html

27. WhatIs. (2013). LinkedIn. Retrieved from: http://whatis.techtarget.com/definition/LinkedIn

28. WikiHow. (Not dated). How to use Google+ hangouts for teaching. Retrieved from: http://www.wikihow.com/Use-Google\%2B-Hangouts-for-Teaching 
NOTES 